\title{
Amygdalus Scoparia as a New Feedstock for Biodiesel Production
}

\author{
Motahareh Vares ${ }^{1}$, Mohammad Reza Sarmasti Emami ${ }^{1}$, Kambiz Tahvildari ${ }^{2} \&$ Mohammad Amin Vares ${ }^{3}$ \\ ${ }^{1}$ Department of chemical engineering, Mazandaran University of Science and Technology, Mazandaran, Iran \\ ${ }^{2}$ Department of chemistry, Islamic Azad University, North Tehran Branch, Tehran, Iran \\ ${ }^{3}$ Department of chemical engineering, University of New South Wales, Sydney, Australia \\ Correspondence: Motahareh Vares, Department of chemical engineering, Mazandaran University of Science and \\ Technology, Mazandaran, Iran. Tel: 98-912-721-0651. E-mail: motahareh.vares@gmail.com
}

Received: March 7, 2016

Accepted: March 20, 2016

Online Published: June 15, 2016

doi:10.5539/mas.v10n8p112

URL: http://dx.doi.org/10.5539/mas.v10n8p112

The research is financed by Mazandaran University of Science and Technology.

\begin{abstract}
Biodiesel is an attractive alternative fuel because of its nontoxicity and biodegradability which can be produced from vegeTable oils and animal fats. Finding a proper feedstock has an important role on the biodiesel characteristics and the price. Therefore in this research, amygdalus Scoparia oil was used as a cheap potential feedstock for biodiesel production which is widespread in arid regions in Iran. This native plant contains 58-60\% oil which is consist of $62.81 \%$ oleic acid and $23.54 \%$ linoleic acid. Biodiesel was produced from transesterification of extracted oil in reaction with methanol in the presence of potassium hydroxide as a catalyst. The reaction variables used were methanol/oil molar ratio (4:1-7:1), catalyst concentration $(0.25-1.5 \%)$, and reaction time $(1-7 \mathrm{~h})$. Optimal conditions for methanolysis were $1 \% \mathrm{KOH}$ concentration, $\mathrm{MeOH} / \mathrm{oil}$ of molar ratio $6: 1$ for a period of $7 \mathrm{~h}$. The yield of biodiesel produced under optimal conditions were 97.32. Overall, amygdalus Scoparia kernel is a promising feedstock for biodiesel production and large cultivation will help to reduce the product cost.
\end{abstract}

Keywords: biodiesel, amygdalus scoparia, transesterification, optimization

\section{Introduction}

Vehicular pollutant emissions, request for the reaction of greenhouse gas emission and crude oil price fluctuations have played the pivotal role to search for renewable energy sources (Buasri, Chaiyut, Loryuenyong, Rodklum, Chaikwan, 2012; Vyas and Verma, 2011). In recent years, for petroleum based diesel fuel; biodiesel is receiving cumulative attention as substitute (Baroutian, Aroua, Raman, Sulaiman, 2011). For use in compression-ignition (diesel) engines, biodiesel defined as a fuel comprised of mono alkyl esters of fatty acids with long-chain originated from renewable lipid feed stocks, such as animal fats or vegeTable oils.

Its chief benefits are that is one of the most viable renewable fuels and likewise it is biodegradable and non-toxic. Furthermore, it is unswervingly applicable in most diesel engines deprived of necessitating comprehensive engine modifications (Younis and Gardy, 2014). Additionally, biodiesel is able to support a few strategies for addressing general concerns such as decreasing air pollution and associated public health risks, leveraging restricted supplies of fossil fuels, and diminishing dependency on foreign petroleum. Nevertheless, their usage has constructed various concerns such as the food contrasted with fuel crisis and chief environmental issues such as usage of a large amount of the accessible arable land, deforestation and serous destruction of vital soil resources (Atabani and César, 2014).

The four technologies for modified crude oils to biodiesel are transesterification, thermal cracking micro-emulsions and blending (Yang, Takase, Zhang, Zhao, Wu, 2014).The transesterification of oils (triglycerides) with simple alcohols in the existence of a catalyst has long been the ideal technique aimed at preparing biodiesel. Figure 1 is a simplified form of the transesterification reaction (Atadashi, Aroua, Aziz, Sulaiman, 2011). Where R1, R2 and R3 are long chains of hydrogen atoms and carbons, occasionally entitled fatty acid chains. 


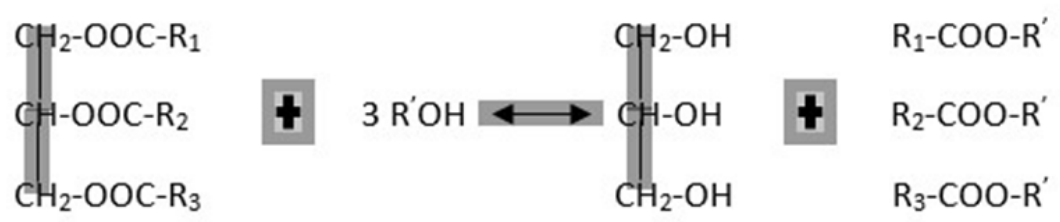

Figure 1. Transesterification reaction of triglyceride to biodiesel

At present, biodiesel can be obtained from a range of natural oils such as rapeseed oil and soybean oil. In the United States, biodiesel is being prepared from soybean oil since extra soybean oil is manufactured than all other sources of oil combined and fats. In Europe, rapeseed oil that is a close cousin of canola oil, leads the growing biodiesel industry. There are various applicants for feed stocks, including animal fats, recycled cooking oils and an assortment of further oilseed crops. Studies specify that the cost of feedstock from edible sources contribute approximately $60-75 \%$ of entire cost of biodiesel production (Yang ET AL, 2014; Atadashi et al, 2011). As a result, the selection biodiesel feedstock is principally based on the cost and the accessibility. The yield per hectare and the oil percentage are significant restrictions to deliberate as biodiesel source (S. P. Singh and D. Singh, 2010). consequently, choosing the low-cost feed stock is vigorous to assurance the biodiesel low production cost (Atabani and César, 2014).

The main aim of this paper is to introduce the Amygdalus scoparia kernel as a new promising feedstock for biodiesel production. Some standard specifications of the produced biodiesel are also measured and compared with international standards (ASTM D6751 and EN14214).

\section{Method}

\subsection{Materials}

In this study Amygdalus scoparia kernel was used in the production of methyl ester. A number of physical properties of this oil are given in Table 1 . The oil contains extraordinary unsaturated fatty acids with $62.98 \%$ oleic acid and $23.54 \%$ linoleic acid.

Table 1. Some physical properties of Amygdalus scoparia oil

\begin{tabular}{cc}
\hline Physical properties & Amount \\
\hline Kinematic viscosity, cSt at $40^{\circ} \mathrm{C}$ & 34.1 \\
Density, g cm-3 & 0.91 \\
Pour point, oC & 4 \\
Flash point, oC & 300 \\
Acid value, mg KOH/g oil & 0.410 \\
Water content & 0.10 \\
\hline
\end{tabular}

Amygdalus scoparia is native to arid regions of Iran. A family member of Rosacea, the species is a noble nominee for desert reclamation. It is a low-cost and abundant seed oil resource in arid lands of Iran which has been used for the first time in this project. A large amount of seeds can bear from Amygdalus scoparia trees in a season. Fig 2 shows tree and Kernel of Amygdalus scoparia feed stock. This feed stock does not emulate with food crops and has high level of oil yield (approximately 60\%). Table 2 shows oil content of conventional feed stocks (Atabani and César, 2014; S. P. Singh and D. Singh, 2010; Takase et al, 2015; Borugadda and Goud, 2012; Karmakar, Karmakar, Mukherjee, 2012). 


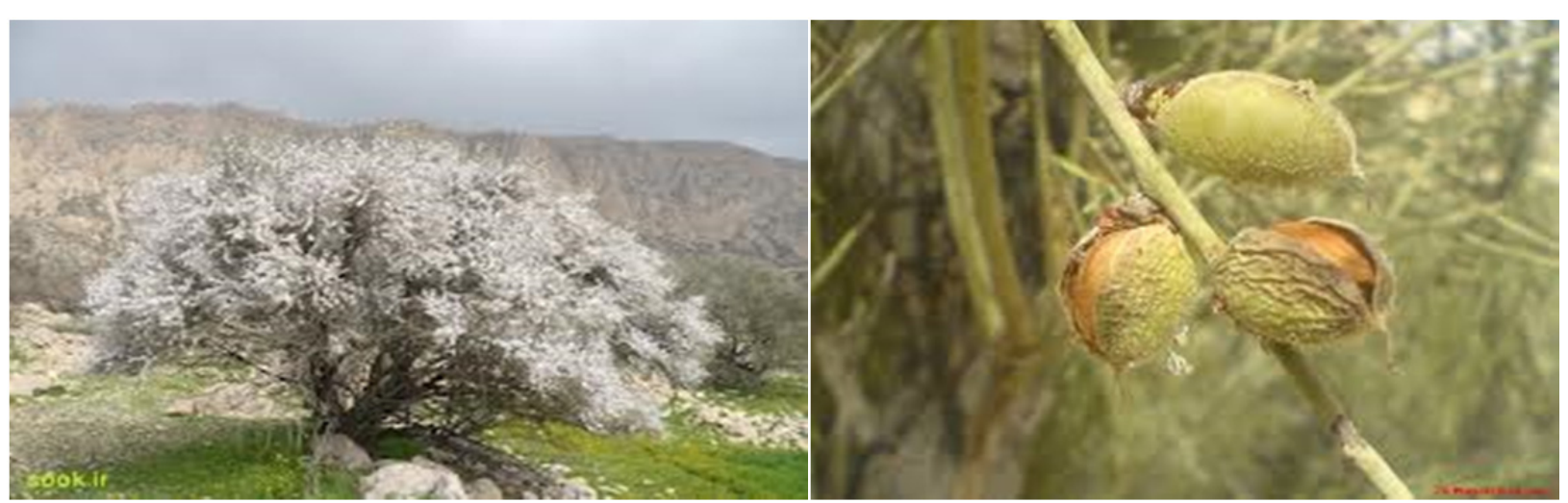

Figure 2. Amygdalus scoparia tree and kernel

Table 2. Oil content of conventional feed stocks for biodiesel production

\begin{tabular}{cc}
\hline Feed stock & Oil wt. \% \\
\hline Palm oil & $46-54 \%$ \\
Castor & $43-45 \%$ \\
Sun flower & $38-48 \%$ \\
Soybean & $17-25 \%$ \\
Colza & $40-48 \%$ \\
Karanja & $25-50 \%$ \\
Jatropha & $40-60 \%$ \\
\hline
\end{tabular}

Pure potassium hydroxide (98.9\%) for transesterification has been used as a catalyst which purchased from Merck Company. Methanol of $99 \%$ purity was used from same company. All the applied chemicals were analytical reagent grade.

\subsection{Extraction of Oil}

Dried Amygdalus scoparia kernel were ground in to particles of $0.5-0.8 \mathrm{~mm}$. The process of oil extraction was performed through application of soxhlet extractor with n-hexane as solvent for $15 \mathrm{~h}$. Then, by passing through a filter nearly all the impurities and particle get separated from the stream and oil was separated from n-hexane through rotary evaporator.

\subsection{Transesterification}

Approximately $50 \mathrm{~g}$ of the Amygdalus scoparia oil was pre-heated to the set temperature $(60-65 \mathrm{oC})$ before starting the reaction. A mixture composed of $0.5 \mathrm{~g} \mathrm{KOH}$ and $11 \mathrm{~g}$ methanol was added to the pre-heated oil. The transesterification was performed in a round-bottomed flask for $5 \mathrm{~h}$ at a temperature of $60-65 \mathrm{oC}$ under reflax while the mixture was being stirred. After the completion of reaction, alcohol was removed with rotary evaporator. Mixture was formerly transmitted to a separatory funnel for phase separation. The lower phase consisted of the glycerol and other impurities and the upper phase involved of methyl esters. For purifying produced biodiesel washing operation by hot distilled water $(65 \mathrm{oC})$ was used. The process of washing was reiterated while waiting for the lower layer reached a $\mathrm{pH}$ similar to the $\mathrm{pH}$ of distilled water. Finally, the methyl ester dried with anhydrous $\mathrm{Na} 2 \mathrm{SO} 4$ to eliminate of any water. The transesterification process was studied at three alcohol-to-oil molar ratios $(5: 1,6: 1$, and $7: 1)$ and three catalyst concentrations $(0.5,1.0$ and $1.5 \% \mathrm{KOH}$ $\mathrm{w} / \mathrm{w} \%)$ at a reaction time (1-5h). The yield of biodiesel was determined using following equation:

$$
\text { Yield of FAME }(\%)=\text { Weight of esters }(\mathrm{g}) / \text { Weight of oil }(\mathrm{g})
$$

\section{Results}

\subsection{Ester Characterization}

The properties of FAME obtained from Amygdalus scoparia are concise in Table 3. As could be perceived, biodiesel properties confirming the ASTM D6751 and EN14214 standards (Tariq, Ali, F. Ahmad, M. Ahmad, Zafar, 2011). 
Table 3. Physicochemical properties of crude Amygdalus scoparia oil methyl ester

\begin{tabular}{ccccc}
\hline Characteristics & Unit & Measured value & Limits (ASTM) & Limits (EN) \\
\hline Viscosity at 40oC & $\mathrm{mm} 2 \mathrm{~s}-1$ & 4.51 & $1.9-6.0$ & $3.5-5.0$ \\
Density at $15 \mathrm{oC}$ & $\mathrm{g} \mathrm{cm}-3$ & 0.883 & - & $0.86-0.9$ \\
Flash point & $\mathrm{oC}$ & 137.5 & $130 \mathrm{~min}$ & $120 \mathrm{~min}$ \\
Pour point & $\mathrm{oC}$ & -10 & - & - \\
Cetane number & - & 52 & $51 \mathrm{~min}$ & $47 \mathrm{~min}$ \\
Acid value & $\mathrm{mg} \mathrm{KOH} / \mathrm{g}$ oil & 0.14 & $0.5 \mathrm{max}$ & $0.5 \mathrm{max}$ \\
Copper strip corrosión & rating & 1 & $3 \mathrm{max}$ & 1 \\
\hline
\end{tabular}

\subsection{Effect of Catalyst Concentration}

The influence of catalyst concentration were considered with its concentration fluctuating from 0.5 to $1.5 \%$ (based on the weight of Amygdalus scoparia oil) while keeping other process parameters fixed. Results are given in Table 4. As it could be perceived, the superlative methyl ester yield (95.01) was attained for catalyst concentration of $1.0 \%$. At greater concentration than $1.0 \%$, the yield decreased due to soap formation.

Table 4. Effect of catalyst concentration on the yield off biodiesel

\begin{tabular}{cc}
\hline Catalyst concentration & Yield of biodiesel \\
\hline $0.5 \%$ & $87.348 \%$ \\
$1 \%$ & $95.01 \%$ \\
$1.5 \%$ & $84.63 \%$ \\
\hline
\end{tabular}

\subsection{Effect of Methanol/Oil Molar Ratio}

In this section, trials were conducted with range of 5:1 to 7:1 methanol/oil molar ratio. The reaction was unfinished for a molar ratio less than 6:1, therefore, full ester yield was achieved at 6:1 molar ratio. Farther increase resulted in lower yield. The results obtained was displayed in Table 5.

Table 5. Effect of methanol to oil molar ratio on the yield of biodiesel

\begin{tabular}{cc}
\hline Methanol to oil molar ratio & Yield of biodiesel \\
\hline $5: 1$ & $89.63 \%$ \\
$6: 1$ & $95.01 \%$ \\
$7: 1$ & $85.01 \%$ \\
\hline
\end{tabular}

\subsection{Effect of Reaction Time}

The influence of reaction time on the yield of methyl ester was considered at diverse time intervals ranging from 1 to $5 \mathrm{~h}$. The concentration of the catalyst and the molar ratio of methanol/oil as optimized in the previous section were adapted. The outcomes of study revealed that the rate of conversion was growths with reaction time. The results are shown in Table 6.

Table 6. Effect of reaction time on the yield of biodiesel

\begin{tabular}{cc}
\hline Reaction time & Yield of biodiesel \\
\hline 1 & $42.213 \%$ \\
3 & $88.72 \%$ \\
5 & $95.01 \%$ \\
\hline
\end{tabular}

\section{Conclusion}

The production cost of biodiesel from various feed stock is much higher than that of petro-diesel. Therefore, the seed cost and oil content of the feed stocks are the chief formative factors for the economic feasibility of biodiesel production. Amygdalus scoparia kernel is a cheap feedstock which has considerable oil content (approximately 60\%). Based on the results, Amygdalus scoparia can produce great yield of biodiesel with the 
lower production costs. The optimum conditions for transesterification was catalyst concentration of $1 \%(\mathrm{w} /$ $\mathrm{w} \%$ ), methanol to oil molar ratio of $6: 1$ and $5 \mathrm{~h}$ of reaction time. The maximum yields with these conditions were $95.01 \%$. The fuel properties of biodiesel confirming the ASTM D6751 and EN14214 standards. Overall, there is a great potential of Amygdalus scoparia oil as a sustainable source for production of biodiesel.

\section{Acknowledgments}

The authors would like to express their grateful thanks for the financial support of the Mazandaran University of Science and Technology, Mazandaran, Iran.

\section{References}

Atabani, A. E., \& César, S. (2014). Calophyllum inophyllum L . - A prospective non-edible biodiesel feedstock . Study of biodiesel production, properties, fatty acid composition, blending and engine performance. Renew. Sustain. Energy Rev., 37, 644-655. http://dx.doi.org/10.1016/j.rser.2014.05.037

Atadashi, I. M., Aroua, M. K., Aziz, A. R. A., \& Sulaiman, N. M. N. (2011). Membrane biodiesel production and refining technology: A critical review. Renew. Sustain. Energy Rev., 15(9), 5051-5062. http://dx.doi.org/10.1016/j.rser.2011.07.051

Baroutian, S., Aroua, M. K., Raman, A. A. A., \& Sulaiman, N. M. N. (2011). A packed bed membrane reactor for production of biodiesel using activated carbon supported catalyst. Bioresour. Technol., 102(2), 1095-1102. http://dx.doi.org/10.1016/j.biortech.2010.08076

Borugadda, V. B., \& Goud, V. V. (2012). Biodiesel production from renewable feedstocks: Status and opportunities. Renew. Sustain. Energy Rev., 16(7), 4763-4784. http://dx.doi.org/10.1016/j.rser.2012.04.010

Buasri, N.K.A.C., Chaiyut, N., Loryuenyong, V., Rodklum, C., \& Chaikwan, T. (2012).Continous process for biodiesel production in packed bed reactor from waste frying oil using potassium hydroxide supported on jatropha curcas fruit shell as solid catalyst, Appl. Sci., 2, 641-653. http://dx.doi.org/10.3390/app2030641

Karmakar, A., Karmakar, S., \& Mukherjee, S. (2012). Biodiesel production from neem towards feedstock diversification: Indian perspective. Renew. Sustain. Energy Rev., 16(1), 1050-1060. http://dx.doi.org/10.1016/j.rser.2011.10.001

Singh, S. P., \& Singh, D. (2010). Biodiesel production through the use of different sources and characterization of oils and their esters as the substitute of diesel: A review. Renew. Sustain. Energy Rev., 14(1), 200-216. http://dx.doi.org/10.1016/j.rser.2009.07.017

Takase, M., Zhao, T., Zhang, M., Chen, Y., Liu, H., Yang, L., \& Wu, X. (2015). An expatiate review of neem , jatropha, rubber and karanja as multipurpose non-edible biodiesel resources and comparison of their fuel, engine and emission properties. Renew. Sustain. Energy Rev., 43, 495-520. http://dx.doi.org/10.1016/j.rser.2014.11.049

Tariq, M., Ali, S., Ahmad, F., Ahmad, M., \& Zafar, M. (2011). Identification , FT-IR , NMR ( 1 H and 13 C ) and GC / MS studies of fatty acid methyl esters in biodiesel from rocket seed oil. Fuel Process. Technol., 92(3), 336-341. http://dx.doi.org/10.1016/j.fuproc.2010.09.025

Vyas, N. S. M. A. P., \& Verma, J. L., (2011) Effects of molar ratio, alkali catalyst concentration and temperature on transesterification of jatropha oil with methanol under ultrasonic irradiation. Adv. Chem. Eng., 1, 45-50. http://dx.doi.org/10.4236/aces.2011.12008

Yang, L., Takase, M., Zhang, M., Zhao, T., \& Wu, X., (2014). Potential non-edible oil feedstock for biodiesel production in Africa: A survey. Renew. Sustain. Energy Rev., 38, 461-477. http://dx.doi.org/10.1016/j.rser.2014.06.002

Younis, K. S. B. K. A., J. L., \& Gardy, J. L. (2014). Production and characterization of biodiesel from locally sourced sesame seed oil, used looking oil and other commercial vegeTable oils in Erbil-Iraq Kurdistan. Am. J. Appl. Chem., 2(6), 105-111. http://dx.doi.org/10.11648/j.ajac.20140206.12

\section{Copyrights}

Copyright for this article is retained by the author(s), with first publication rights granted to the journal.

This is an open-access article distributed under the terms and conditions of the Creative Commons Attribution license (http://creativecommons.org/licenses/by/3.0/). 